\title{
MUROTTAL MUSIC ON DYSMENORRHEA PAIN \\ AMONG STUDENTS IN MADRASAH ALIYAH SULTAN HASANUDIN, SOUTH JAKARTA
}

\author{
Ova Jayanti, Rosmawati Lubis, Nurmawati
}

Department of Health Sciences, Universitas Nasional Jakarta

\begin{abstract}
Background: The incidence of dysmenorrhea is more than 50\% among women in every country. In the United States, an average of $60 \%$ with the highest prevalence of dysmenorrhea is among adolescent girls, $15 \%$ of whom have severe dysmenorrhea. Dysmenorrhea that is not treated properly can interfere with daily activities. Non-pharmacological handling by listening to murottal music can cause the brain to emit theta waves which cause a sense of calm. This study aimed to examine the murottal music on dysmenorrhea pain among students in Madrasah Aliyah Sultan Hasanudin, South Jakarta.

Subjects and Method: This was an experimental study with one group pretest-posttest designs. Total of 32 students were enrolled in this study. The dependent variable was dysmenorrhea pain. The independent variable was murottal music. The data were analyzed using Wilcoxon Test.

Results: Before the murottal music intervention, 16 students (50\%) had mild pain, 12 students (37.5\%) felt moderate pain, and 4 students (12.5\%) felt severe pain. After the murottal music intervention, 29 out of 32 students felt pain decreased, the intensity felt was in a state of not pain to moderate pain, and it was statistically significant ( $<<0.001)$.

Conclusion: The murottal music decrease the dysmenorrhea pain among students in Madrasah Aliyah Sultan Hasanudin, South Jakarta.
\end{abstract}

Keywords: adolescents, dysmenorrhea, murottal music

Correspondence:

Ova Jayanti. Department of Health Sciences, Universitas Nasional Jakarta, Indonesia.

The $7^{\text {th }}$ International Conference on Public Health Solo, Indonesia, November 18-19, 2020 | 373 https://doi.org/10.26911/the7thicph.05.05 